\title{
Effect of supplementary concentrate type on nitrogen partitioning in early lactation dairy cows offered perennial ryegrass-based pasture
}

\author{
S. J. Whelan, ${ }^{*}$ K. M. Pierce, ${ }^{*}$ C. McCarney,† B. Flynn, ${ }^{\star}$ and F. J. Mulligan ${ }^{1}$ \\ ${ }^{*}$ School of Agriculture and Food Science, University College Dublin Lyons Research Farm, Newcastle, Dublin, Ireland \\ †School of Veterinary Medicine, University College Dublin, Belfield Dublin 4, Ireland
}

\begin{abstract}
Forty-four early lactation $(64 \pm 20 \mathrm{~d}$ in milk) dairy cows of mixed parity were used to assess the effect of 4 supplementary concentrate types $(\mathrm{n}=11)$ on $\mathrm{N}$ partitioning. Animals were blocked on parity and calving date, and blocks were balanced for previous milk yield and milk protein yield. Cows received grazed pasture plus $5.17 \mathrm{~kg}$ of dry matter $(\mathrm{DM}) / \mathrm{d}$ of one of the following isoenergetic concentrates: high crude protein $(\mathrm{CP})$ with rolled barley (HP, 19\% CP); low CP with rolled barley (LP, 15\% CP); low CP with barley and supplementary 2-hydroxy-4-methylthio butanoic acid (HMBi; $\mathrm{LP}+\mathrm{HMBi}, 15 \% \mathrm{CP}$ ); and low $\mathrm{CP}$ with ground corn (LP Corn, $15 \%$ CP). Nitrogen partitioning studies were conducted at wk 6 and 10 postpartum by using the $n$-alkane technique to determine pasture dry matter intake (DMI). Pasture DMI (13.3 kg of DM/d) and dietary digestibility of DM were not affected by concentrate type. Milk yield was lower for LP compared with other concentrate types (25.4 vs. $28.3 \mathrm{~kg} / \mathrm{d})$. Yields of milk protein and milk casein were not affected by concentrate type. However, milk solid yield and milk fat yield were higher for LP + HMBi $(1.97$ and $0.92 \mathrm{~kg} / \mathrm{d})$ compared with LP $(1.72$ and $0.87 \mathrm{~kg} / \mathrm{d})$. Concentrations of fat, protein, lactose, and casein were not affected by concentrate type. Dietary N intake was higher for HP compared with other treatments (0.545 vs. $0.482 \mathrm{~kg} / \mathrm{d}$, $\mathrm{HP}$ vs. average of the $3 \mathrm{LP}$ treatments). Dietary N intakes were not different among low $\mathrm{CP}$ concentrates. Fecal $\mathrm{N}$ excretion was not affected by concentrate type. However, urinary $\mathrm{N}$ excretion was related to $\mathrm{N}$ intake and was higher for HP compared with other treatments (0.261 vs. $0.195 \mathrm{~kg} / \mathrm{d}$, HP vs. average of the $3 \mathrm{LP}$ treatments). Urinary $\mathrm{N}$ excretion was not different among low $\mathrm{CP}$ concentrates. Milk N output was higher for HP $(0.139 \mathrm{~kg} / \mathrm{d})$ compared with LP $(0.12 \mathrm{~kg} / \mathrm{d})$ but not $\mathrm{LP}+\operatorname{HMBi}(0.137 \mathrm{~kg} / \mathrm{d})$ or LP Corn $(0.138 \mathrm{~kg} / \mathrm{d})$.
\end{abstract}

Received July 5, 2011.

Accepted January 17, 2012

${ }^{1}$ Corresponding author: finbar.mulligan@ucd.ie
The portion of feed $\mathrm{N}$ excreted as feces $\mathrm{N}$ was lower for HP compared with other treatments $(0.272$ vs. 0.327 , HP vs. average of the $3 \mathrm{LP}$ treatmentsHowever, the portion of feed $\mathrm{N}$ excreted as urine $\mathrm{N}$ was higher for HP (0.466) compared with LP + HMBi (0.408) and LP Corn (0.366) but not compared with LP. The portion of feed $\mathrm{N}$ excreted as milk $\mathrm{N}$ was higher for LP Corn (0.282) compared with HP (0.257) but not LP $+\mathrm{HMBi}$ or LP. Dietary reformulation to reduce N excretion in pasture-based dairy production systems is possible. However, maintenance of milk yield and milk $\mathrm{N}$ when concentrate $\mathrm{CP}$ was reduced (19 vs. $15 \%$ ) required the use of either protected AA (HMBi) or ground corn.

Key words: dairy cow, nitrogen balance, milk production, grazing

\section{INTRODUCTION}

Nitrogen losses from dairy production systems have a detrimental effect on air quality $\left(\mathrm{NH}_{3}\right)$ and water quality $\left(\mathrm{NO}_{3}\right)$ and contribute to the greenhouse effect $\left(\mathrm{N}_{2} \mathrm{O}\right)$ (Tamminga, 1992). In an effort to abate the losses of $\mathrm{N}$ to the environment, dairy farmers operating in the European Union must adhere to strict environmental controls (European Communities, 2009). Irish dairy farmers operate predominantly pastoral-based, seasonal-calving milk production systems; consequently, a large portion of $\mathrm{N}$ loss occurs when animals are outdoors grazing (Hyde et al., 2003; Casey and Holden, 2005). Therefore, it is of interest to develop dietary strategies that manipulate $\mathrm{N}$ excretion routes and thus reduce the environmental burden of pasture-based dairy production.

When grazed pasture is the sole feed offered to the dairy cow, the opportunity for dietary manipulation of $\mathrm{N}$ excretion, and urinary $\mathrm{N}$ excretion in particular, is limited. However, supplementation with a concentrate feed, which is often required in early lactation (Bargo et al., 2002), presents an opportunity to reduce N excretion from dairy cows through manipulation of the concentrate type offered. Previous studies have shown that reducing concentrate $\mathrm{CP}$ reduces total $\mathrm{N}$ excretion, in 
particular urinary $\mathrm{N}$ excretion, from dairy cows offered grazed pasture (Mulligan et al., 2004; Burke et al., 2008). However, these studies were conducted in dairy cows averaging 92 DIM (Mulligan et al., 2004) and 140 DIM (Burke et al., 2008) and may not accurately reflect a situation when intakes are low and the demand for protein is high, as is the case in early lactation (Schor and Gagliostro, 2001). Broderick (2003) showed that when dairy cows are offered a TMR and dietary CP intake is reduced (18.4 vs. $15.1 \% \mathrm{CP}$ ), concurrent decreases in milk yield ( $34.1 \mathrm{vs.} 33 \mathrm{~kg} / \mathrm{d}$ ) and milk protein yield (1.02 vs. $0.99 \mathrm{~kg} / \mathrm{d})$ occur. When dairy cows are offered grazed pasture, the supply of CP is not likely to limit production. However, the rapid degradation of $\mathrm{N}$ and the slower degradation of energy in the rumen results in poor assimilation of $\mathrm{N}$ into microbial mass. Consequently, the supply of AA available postrumen may limit production (Schor and Gagliostro, 2001).

Of these AA, methionine has been suggested to be first-limiting (NRC, 2001) and, in several feeding situations, the addition of rumen-protected methionine or a methionine hydroxy analog (2-hydroxy-4-methylthio butanoic acid, HMBi) has been shown to improve yields of milk and milk protein (Noftsger and St-Pierre, 2003; Broderick et al., 2008; Phipps et al., 2008). However, in the literature reports are scarce on the effects of supplementary methionine when cows are offered predominantly grazed pasture in the diet. Therefore, it is of interest to investigate if supplementing low $\mathrm{CP}$ concentrates with a methionine source could reduce $\mathrm{N}$ excretion through improvements in milk protein yield.

Manipulation of $\mathrm{N}$ partitioning is also possible through altering the site of starch digestion. Replacing rolled barley with ground corn will increase the postruminal supply of starch (Ørskov, 1986; Herrera-Saldana et al., 1990) and has been shown to reduce urinary $\mathrm{N}$ excretion through numeric improvements in milk $\mathrm{N}$ and fecal $\mathrm{N}$ when cows were offered grass silage-based diets (Kebreab et al., 2000; Castillo et al., 2001). However, grazed pasture likely contains higher levels of digestible OM than grass silage and to date reports on the effects of grain type on $\mathrm{N}$ partitioning are scarce. Therefore, further exploration of the effect of grain type (i.e., barley vs. corn) on $\mathrm{N}$ partitioning is required for diets that are based predominantly on grazed pasture.

The objectives of the experiment reported herein are to evaluate the effects of (1) reducing concentrate $\mathrm{CP}$, (2) supplementing low CP concentrates with a source of methionine, and (3) replacing rolled barley with ground corn in low $\mathrm{CP}$ concentrates on milk production and $\mathrm{N}$ partitioning in early lactation dairy cows offered perennial ryegrass-based pasture.

\section{MATERIALS AND METHODS}

\section{Animals and Management}

All procedures described in this experiment were conducted under experimental license from the Irish Department of Health and Children in accordance with the Cruelty to Animals Act 1876 and the European Communities (Amendments of the Cruelty to Animals Act 1876) Regulations, 1994.

Twenty primiparous and 24 multiparous dairy cows (Bos taurus strain Holstein-Friesian) were selected from the spring-calving dairy herd at UCD Lyons Research Farm, Newcastle, Dublin, Ireland $\left(53^{\circ} 17^{\prime} 56^{\prime \prime} \mathrm{N}\right.$, $\left.6^{\circ} 32^{\prime} 18^{\prime \prime} \mathrm{W}\right)$. Animals were blocked on parity and calving date and assigned to 1 of 4 pasture-based dietary treatments in a randomized complete block design (n $=11$ ). Blocks were balanced for previous lactation milk yield $(7,432 \pm 844 \mathrm{~kg})$ and milk protein yield $(253 \pm 30$ $\mathrm{kg})$. Animals were assigned to concentrate treatments from d 1 postpartum.

Treatments consisted of a concentrate feed offered supplementary to a perennial ryegrass-based pasture. Concentrate treatments were (1) a high protein $(19 \%$ $\mathrm{CP})$ concentrate (HP); (2) a low protein $(15 \% \mathrm{CP})$ concentrate (LP); (3) a low protein $(15 \% \mathrm{CP})$ concentrate plus supplementary HMBi $(\mathbf{L P}+\mathbf{H M B i})$; and (4) a low protein $(15 \% \mathrm{CP})$ concentrate containing stone-ground corn (LP Corn; Table 1). A reduction in $\mathrm{CP}$ was achieved by replacing soybean meal with cereal grains and digestible fiber. In HP, LP, and LP $+\mathrm{HMBi}$, rolled barley was used as the starch source, whereas in LP Corn, rolled barley was replaced with stone-ground corn (Gain Feeds, Glanbia plc, Kilkenny, Ireland). Concentrates were isoenergetic [1.11 units of energy for milk production (unité fourragère lait, UFL) $/ \mathrm{kg}$ of DM], and low CP concentrates (LP, LP + HMBi, and LP Corn) were isonitrogenous $[11.2 \%$ protein truly digested in the small intestine (PDI)], whereas HP contained $13.9 \%$ PDI (Table 2). Animals received the concentrate portion of their diet twice daily during milking at a rate of $2.58 \mathrm{~kg}$ of $\mathrm{DM} / \mathrm{head}$ (total $5.17 \mathrm{~kg}$ of $\mathrm{DM} /$ head per day).

All cows were grazed together and were offered fresh allocations (10 kg of DM/head) of pasture twice daily (20 kg of DM/head per day, total). Pregrazing herbage mass was determined using the quadrat and shears method. Briefly, an area $\left(0.25 \mathrm{~m}^{2}\right)$ was cut using a handheld shears (Gardena Accu 90, Gardena GmbH, Ulm, Germany) to a height of $4 \mathrm{~cm}$ at 6 random locations throughout the paddock. Each $0.25 \mathrm{~m}^{2}$ of grass was then collected and weighed, and a sample of pasture was 
Table 1. Ingredient inclusion rate of concentrates offered during the experiment

\begin{tabular}{|c|c|c|c|c|}
\hline \multirow[b]{2}{*}{ Ingredient ( $\%$ of DM) } & \multicolumn{4}{|c|}{ Concentrate $^{1}$} \\
\hline & $\mathrm{HP}$ & LP & $\mathrm{LP}+\mathrm{HMBi}$ & LP Corn \\
\hline Barley grain & 47.5 & 50.0 & 50.0 & 0 \\
\hline Corn grain & 0 & 0 & 0 & 50.0 \\
\hline Beet pulp & 11.1 & 23.1 & 23.6 & 11.7 \\
\hline Citrus pulp & 6.8 & 4.6 & 3.8 & 4.2 \\
\hline Soy hulls & 0 & 0 & 0 & 8.3 \\
\hline Soybean meal & 25.1 & 12.6 & 12.1 & 16.2 \\
\hline Metasmart $^{2}$ & 0 & 0 & 0.8 & 0 \\
\hline $\mathrm{CPO}^{3}$ coater & 0.6 & 0.6 & 0.6 & 0.6 \\
\hline Milk solids & 5.0 & 5.0 & 5.0 & 5.0 \\
\hline Monocalcium diphosphate & 1.1 & 1.4 & 1.4 & 1.3 \\
\hline Limestone flour & 0.7 & 0.6 & 0.6 & 0.6 \\
\hline Salt & 0.6 & 0.6 & 0.6 & 0.6 \\
\hline Calcined magnesite & 0.9 & 0.9 & 0.9 & 0.9 \\
\hline Trace elements + vitamins ${ }^{4}$ & 0.6 & 0.6 & 0.6 & 0.6 \\
\hline \multicolumn{5}{|c|}{$\begin{array}{l}{ }^{1} \mathrm{HP}=\text { high } \mathrm{CP} \text { concentrate; } \mathrm{LP}=\text { low } \mathrm{CP} \text { concentrate } \mathrm{LP}+\mathrm{HMBi}=\text { low } \mathrm{CP} \text { concentrate containing supple- } \\
\text { mentary 2-hydroxy-4-methylthio butanoic acid }(\mathrm{HMBi}) ; \mathrm{LP} \text { Corn }=\text { low } \mathrm{CP} \text { concentrate where corn replaces } \\
\text { rolled barley. }\end{array}$} \\
\hline \multicolumn{5}{|c|}{$\begin{array}{l}{ }^{2} \text { Metasmart (Adisseo France SAS, Anthony, France) consisted of not less than } 57 \% \text { monomer esters of HMBi, } \\
4 \% \text { maximum humidity. }\end{array}$} \\
\hline \multicolumn{5}{|l|}{${ }^{3} \mathrm{CPO}=$ crude palm oil. } \\
\hline \multicolumn{5}{|c|}{$\begin{array}{l}{ }^{4} \text { Trace elements }+ \text { vitamins consisted of the following: } 10 \mathrm{IU} / \mathrm{kg} \text { of vitamin E, } 2.5 \mathrm{mg} / \mathrm{kg} \text { of Co, } 10 \mathrm{mg} / \mathrm{kg} \text { of I, } \\
6.5 \mathrm{mg} / \mathrm{kg} \text { of Se, } 37 \mathrm{mg} / \mathrm{kg} \text { of Cu, } 50 \mathrm{mg} / \mathrm{kg} \text { of } \mathrm{Mn} \text {, and } 125 \mathrm{mg} / \mathrm{kg} \text { of Zn. Vitamins consisted of the following: } \\
8,000 \mathrm{IU} / \mathrm{kg} \text { vitamin A, 2,000 IU } / \mathrm{kg} \text { vitamin } \mathrm{D}_{3} \text {. }\end{array}$} \\
\hline
\end{tabular}

taken for determination of DM and routine chemical analysis. Average pregrazing herbage mass was 1,966 \pm $602 \mathrm{~kg}$ of $\mathrm{DM} / \mathrm{ha}$, and postgrazing herbage mass was $520 \pm 216 \mathrm{~kg}$ of $\mathrm{DM} / \mathrm{ha}$. The chemical composition of the pasture offered during this experiment is presented in Table 2. The pasture offered during this experiment was estimated to contain $97 \%$ perennial ryegrass ( $\mathrm{Lo}$ lium perenne) and 3\% white clover (Trifolium repens).

Table 2. Chemical composition of supplementary concentrates and pasture offered during the experiment

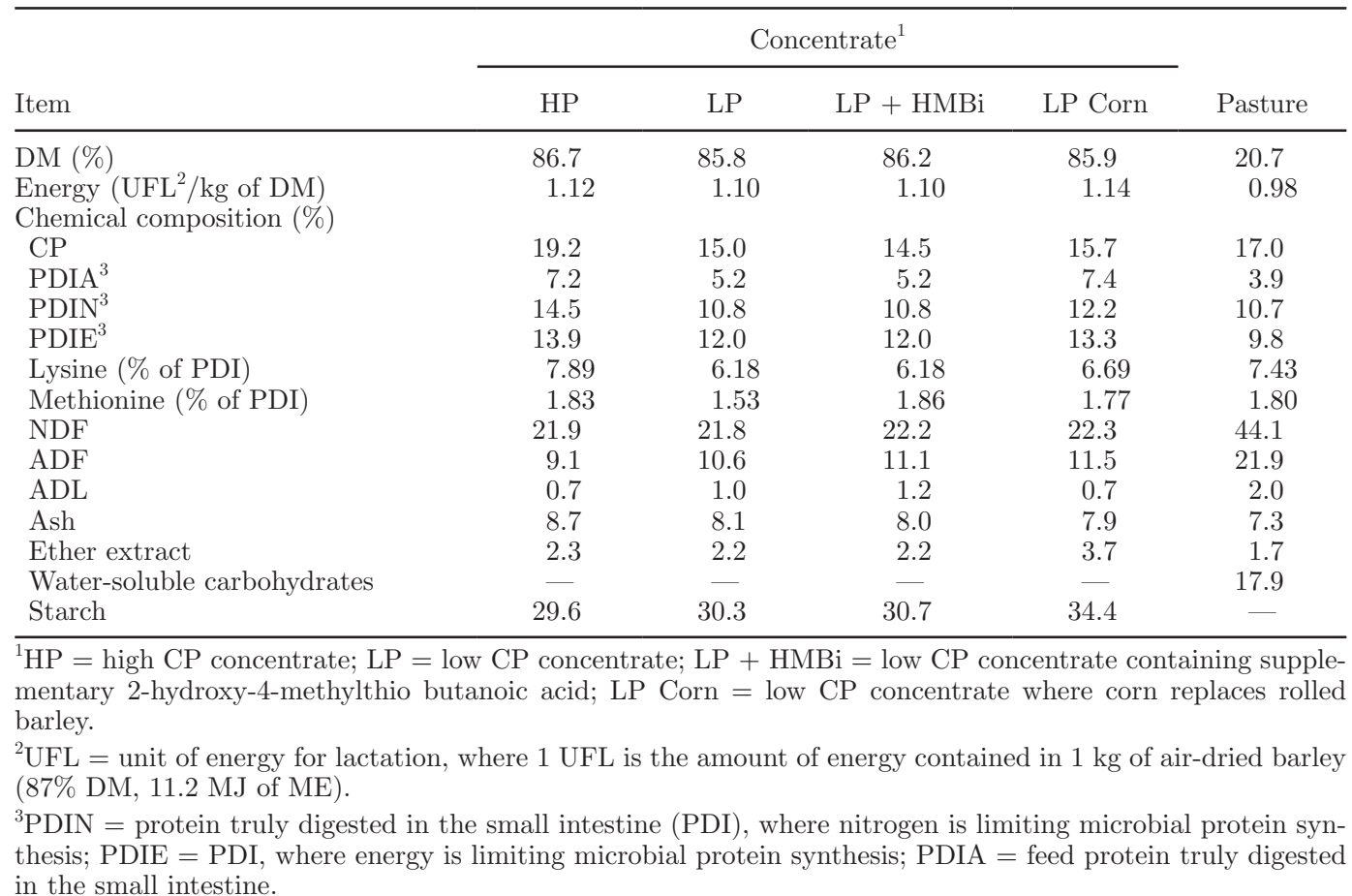


Pastures received chemical $\mathrm{N}$ in February $(29 \mathrm{~kg} / \mathrm{ha})$, March (58 kg/ha), and April (58 kg/ha).

Cows were milked twice daily at 0700 and $1600 \mathrm{~h}$ for the duration of the experiment. Recording and sampling of milk output was achieved using the Weighall milk meter system (Dairymaster, Causeway, Kerry, Ireland).

\section{Nitrogen Partitioning Study}

Nitrogen partitioning studies were conducted during wk 6 (47 \pm 10 DIM) and $10(82 \pm 10$ DIM $)$ postpartum, corresponding to periods 1 and 2, respectively. To facilitate calculation of $\mathrm{N}$ intake and fecal $\mathrm{N}$ excretion, pasture DMI and diet DM digestibility (DMD) were estimated for a period of $6 \mathrm{~d}$ during this time. Determination of pasture DMI was achieved using the $n$-alkane technique of Mayes et al. (1986), as described in Mulligan et al. (2004). Briefly, individual animals were dosed, following am and pm milking, with a paper bolus impregnated with $500 \mathrm{mg}$ of the $n$-alkane $n$-dotriacontane (C32) for a period of $12 \mathrm{~d}$. On the last $6 \mathrm{~d}$ of each $\mathrm{N}$ balance period, pasture samples were collected using a hand-held shears (described previously) during am and pm grazing. Pasture samples were then bowlchopped (Hobart 842181, Hobart Corporation, Troy, $\mathrm{OH})$ to give a homogeneous sample length and lyophilized (Labconco Freezone 18, Labconco Corp., Kansas City, MO). Fecal samples were collected per rectum on the last $6 \mathrm{~d}$ following am and pm milking. Feces were dried immediately at $55^{\circ} \mathrm{C}$ for $72 \mathrm{~h}$. Milk samples were collected daily during am and pm milking and pooled in proportion to yield for each $\mathrm{N}$ partitioning study. Milk samples were frozen to $-20^{\circ} \mathrm{C}$ before analysis. Daily concentrate samples were collected, pooled for each N partitioning study, and dried at $104^{\circ} \mathrm{C}$ for $24 \mathrm{~h}$. Body weight $(500 \pm 16 \mathrm{~kg})$ and $\mathrm{BCS}(3.0 \pm 0.08)$ were determined at the beginning and end of each period.

\section{Sample Analyses}

Dried pasture, concentrate, and feces samples were ground in a hammer mill fitted with a 1-mm screen (Lab Mill, Christy Turner, Suffolk, UK). Ground feces samples were composited per cow per $\mathrm{N}$ balance period, and daily grass and concentrate samples were composited per N balance period. Neutral detergent fiber and ADF were determined by the method of Van Soest et al. (1991) using the Ankom 220 Fiber Analyzer (Ankom Technology, Fairport, NY). A thermo-stable $\alpha$-amylase (17,400 Liquefon units/mL, Ankom Technology) was used when concentrate NDF was determined. Acid detergent lignin was determined following ADF determination by soaking the sample in $72 \% \mathrm{H}_{2} \mathrm{SO}_{4}$ for $3 \mathrm{~h}$ and then triple rinsing with distilled $\mathrm{H}_{2} \mathrm{O}$ before drying at $104^{\circ} \mathrm{C}$ for $3 \mathrm{~h}$. Ash was determined following combustion in a muffle furnace (Nabertherm $\mathrm{GmbH}$, Lilienthal, Germany) at $550^{\circ} \mathrm{C}$ for $5 \mathrm{~h}$. Digestible organic matter (DOM) was calculated as follows: DOM $=\{[\mathrm{DMI} \times(100-$ ash $\%$ of feed $)]-[$ feces DM output $\times(100-$ ash $\%$ of feces $)]\}$. Starch was determined using the Megazyme Total Starch Assay Procedure (cat no. K-TSTA, Megazyme International Ireland Ltd., Wicklow, Ireland). Gross energy (GE) was determined by bomb calorimetry (Parr 1281 bomb calorimeter, Parr Instrument Company, Moline, IL). Ether extract (EE) was determined using Soxtec instruments (Tecator, Höganäs, Sweden) and light petroleum ether. From these data, fermentable organic matter (FOM) was calculated as follows: $\mathrm{FOM}=\mathrm{DOM}-\mathrm{EE}-$ undegradable dietary protein. The $\mathrm{N}$ content of the pasture, concentrate, and feces samples were determined by combustion (FP 528 Analyzer, Leco Corp., St Joseph, MI). These data were then used to calculate $\mathrm{N}$ partitioning, as follows: $\mathrm{N}$ intake $=\{[$ pasture DMI $\times \% \mathrm{~N}$ in pasture $\div 100]+$ (concentrate DMI $\times \% \mathrm{~N}$ in concentrate $\div 100$ ) $\}$; fecal $\mathrm{N}=($ fecal $\mathrm{DM}$ excretion $\times \% \mathrm{~N}$ in feces $\div 100)$; milk $\mathrm{N}=$ (milk yield $\times \% \mathrm{~N}$ in milk $\div 100)$; and urine $\mathrm{N}=$ $(\mathrm{N}$ intake - fecal $\mathrm{N}-$ milk $\mathrm{N})$.

Values for feed protein truly digestible in the small intestine (PDIA); protein truly digestible in the small intestine, where $\mathrm{N}$ is limiting microbial protein synthesis (PDIN); and protein truly digestible in the small intestine, where energy is limiting microbial protein synthesis (PDIE) of each dietary treatment were calculated using the following equations of Jarrige (1989):

$$
\begin{gathered}
\mathrm{PDIA}=1.11 \times \mathrm{CP} \times(1-\mathrm{deg}) \times \mathrm{dsi}, \\
\mathrm{PDIN}=\mathrm{PDIA}+[0.64 \times \mathrm{CP} \times(\mathrm{deg}-0.1)], \text { and } \\
\mathrm{PDIE}=\mathrm{PDIA}+(\mathrm{FOM} \times 0.093),
\end{gathered}
$$

where deg is the theoretical degradability of feeds in sacco, and dsi is true digestibility of undegraded dietary protein in the small intestine. Both deg and dsi were obtained from published data (Jarrige, 1989), whereas CP was determined as described previously for feed. Rumen-degradable protein balance $\left(\mathbf{R D P}_{\text {bal }}\right)$ was calculated as follows:

$$
\begin{gathered}
\mathrm{RDP}_{\text {bal }}=\left[\left(\mathrm{DMI}_{\text {pasture }} \times \mathrm{PDIN}_{\text {pasture }}\right)+\left(\mathrm{DMI}_{\text {conc. }}\right.\right. \\
\left.\left.\times \mathrm{PDIN}_{\text {conc. }}\right)\right]-\left[\left(\mathrm{DMI}_{\text {pasture }} \times \mathrm{PDIE}_{\text {pasture }}\right)\right. \\
\left.+\left(\mathrm{DMI}_{\text {conc. }} \times \mathrm{PDIE}_{\text {conc. }}\right)\right]
\end{gathered}
$$

where conc. $=$ concentrate. Methionine and lysine as a percentage of PDI supply were calculated based on previously published data for pasture (van Vuuren et 
al., 1992; Peyraud et al., 1997; Rulquin et al., 2001) and concentrates (McDonald et al., 2002). Microbial protein supply was assumed to have a constant AA profile, whereas PDIA was assumed to have an AA profile similar to the ingested feedstuff (Allison and Garnsworthy, 2002).

$n$-Alkanes were extracted from pasture, concentrate, and feces samples according to the method of Dove and Mayes (2006). Following extraction, samples were analyzed for concentrations of $n$-alkanes by gas chromatography using a Varian 3800 GCL (Varian Inc., Palo Alto, CA) fitted with a 30-m capillary column with an internal diameter of $0.53 \mathrm{~mm}$ coated with 0.5 $\mu \mathrm{m}$ dimethyl polysiloxane (SGE Analytical Science Pty. Ltd., Ringwood, Victoria, Australia). These data were then applied to the following formulas to calculate pasture DMI and DMD:

$$
\begin{gathered}
\mathrm{DMI}=\{\mathrm{Fi} / \mathrm{Fj} \times[\mathrm{Dj}+(\mathrm{Ic} \times \mathrm{Cj})] \\
-[\mathrm{Ic} \times \mathrm{Ci}]\} /[\mathrm{Hi}-(\mathrm{Fi} / \mathrm{Fj} \times \mathrm{Hj})] \text { and } \\
\mathrm{DMD}=1-[\text { dietary C35 }(\mathrm{mg} / \mathrm{kg}) / \\
\text { fecal C35 }(\mathrm{mg} / \mathrm{kg})],
\end{gathered}
$$

where $\mathrm{Fi}$ and $\mathrm{Fj}$ are the concentrations of naturally occurring odd-chain (mainly feed-derived C33) and even-chain (mainly dosed C32) $n$-alkanes in feces, respectively $(\mathrm{mg} / \mathrm{kg})$; Hi and $\mathrm{Hj}$ are the concentrations of natural odd-chain and even-chain $n$-alkanes in pasture, respectively $(\mathrm{mg} / \mathrm{kg}) ; \mathrm{Dj}$ is the daily dose rate of evenchain $n$-alkanes $(\mathrm{mg} / \mathrm{kg})$; and Ic is the daily concentrate intake (kg/d) (Mulligan et al., 2004).

Concentrations of milk fat, protein, and lactose were determined in a commercial milk laboratory (Progressive Genetics, Bluebell, Dublin, Ireland) using infrared analysis (CombiFoss 5000, Foss Analytical A/S, Hillerød, Denmark). Milk samples were prepared for analysis according to International Dairy Federation (IDF) method 29-2:2004 (IDF, 2004). Milk N was determined by combustion as described previously for feed and casein $\mathrm{N}$ was analyzed using the micro-Kjeldahl technique as per IDF method 29-2:2004 (IDF, 2004). Milk urea $\mathrm{N}$ was determined using the Randox Urease-Berthelot colorimetric method (cat no. UR1068, Randox Laboratories, Crumlin, Antrim, UK) as described in Mulligan et al. (2004).

\section{Statistical Analyses}

Data were checked for adherence to the normal distribution and homogeneity of variance using histograms and formal statistical tests as part of Proc Univariate of SAS Institute (2004). The relationships between feed
$\mathrm{N}$ intake $(\mathrm{kg} / \mathrm{d})$ and $\mathrm{N}$ excretion in urine, feces, and milk were tested for linear effects using Proc GLM of SAS Institute (2004). Analysis of data was conducted using Proc Mixed of SAS Institute (2004). The model included tests for the fixed effects of treatment, period, and parity and their interactions. Statistically significant differences between least squares means were tested using the PDIFF command, incorporating the Tukey test for pairwise comparison of treatment means. The overall model was as follows:

$$
\mathrm{Y}_{\mathrm{ijk} \mathrm{k}}=\mu+\tau_{\mathrm{j}}+\mathrm{x}_{\mathrm{k}}+\omega_{\mathrm{l}}+\tau \mathrm{x}_{\mathrm{jk}}+\tau \omega_{\mathrm{jl}}+\varepsilon_{\mathrm{ijk} \mathrm{l}},
$$

where $Y_{\mathrm{ijkl}}=$ ith cow in the jth treatment of the kth period and lth parity; $\tau_{j}=$ fixed effect of treatment, where $\mathrm{j}=\mathrm{HP}, \mathrm{LP}, \mathrm{LP}+\mathrm{HMBi}$, or LP Corn; $\mathrm{x}_{\mathrm{k}}=$ the fixed effect of period, where $\mathrm{k}=$ wk 6 or wk 10 postpartum; $\omega_{1}=$ the fixed effect of parity, where $l=$ primiparous or multiparous; $\tau \mathrm{x}_{\mathrm{jk}}=$ the interaction of the jth treatment with the kth period; $\tau \omega_{\mathrm{jl}}=$ the interaction of the jth treatment with the lth parity; and $\varepsilon_{\mathrm{ijkl}}=$ residual error. When interactions were not significant, these terms were excluded from the model. Statistical significance was assumed at a value of $P<0.05$ and a tendency toward significance assumed at a value of $P>0.05$ but $<0.10$.

\section{RESULTS}

\section{DMI, Digestibility, Milk Production, and Milk Composition}

Table 3 shows the effect of supplementary concentrate type on DMI, DMD, milk yield (MY), milk constituent yield, and milk composition. Pasture DMI $(\mathbf{P D M I})$ and total DMI were not affected $(P=0.16)$ by concentrate type. Similarly, DMD was not different $(P=0.64)$ among treatments. Animals offered LP had lower milk yields compared with those offered HP $(P=$ $0.04), \mathrm{LP}+\mathrm{HMBi}(P=0.03)$, and LP Corn $(P=0.03)$. Milk yields from animals offered HP, LP $+\mathrm{HMBi}$, and LP Corn were not different. Milk fat yield was higher for animals offered LP + HMBi compared with those offered LP $(P=0.01)$. Supplementary concentrate type had no effect on yields of milk protein $(P=0.22)$, casein $(P=0.51)$, or lactose $(P=0.16)$. Similarly, supplementary concentrate type did not affect concentrations of fat $(P=0.59)$, protein $(P=0.11)$, lactose $(P=0.45)$, or casein $(P=0.80)$ in the milk.

\section{Nitrogen Partitioning Study}

Table 4 shows the effect of supplementary concentrate type on $\mathrm{N}$ partitioning. Dietary $\mathrm{N}$ intake was 
Table 3. Effect of supplementary concentrate type on DMI, diet digestibility, and milk production variables

\begin{tabular}{|c|c|c|c|c|c|}
\hline \multirow[b]{2}{*}{ Item } & \multicolumn{4}{|c|}{$\operatorname{Diet}^{1}$} & \multirow[b]{2}{*}{ SEM } \\
\hline & $\mathrm{HP}$ & LP & $\mathrm{LP}+\mathrm{HMBi}$ & LP Corn & \\
\hline \multicolumn{6}{|l|}{ Intake $(\mathrm{kg}$ of $\mathrm{DM} / \mathrm{d}$ ) } \\
\hline Pasture & 14.2 & 12.8 & 13.5 & 12.6 & 0.74 \\
\hline Total & 19.4 & 18.0 & 18.7 & 17.8 & 0.80 \\
\hline Diet $\operatorname{DMD}^{2}(\mathrm{~g} / \mathrm{kg})$ & 0.78 & 0.77 & 0.76 & 0.78 & 0.01 \\
\hline \multicolumn{6}{|l|}{ Milk output (kg/d) } \\
\hline Milk & $28.3^{\mathrm{a}}$ & $25.4^{\mathrm{b}}$ & $28.4^{\mathrm{a}}$ & $28.2^{\mathrm{a}}$ & 0.75 \\
\hline $4 \% \mathrm{FCM}$ & $23.11^{\mathrm{ab}}$ & $21.44^{\mathrm{b}}$ & $25.36^{\mathrm{a}}$ & $23.04^{\mathrm{ab}}$ & 1.20 \\
\hline Fat & $0.92^{\mathrm{ab}}$ & $0.86^{\mathrm{b}}$ & $1.01^{\mathrm{a}}$ & $0.92^{\mathrm{ab}}$ & 0.05 \\
\hline Protein & 0.94 & 0.87 & 0.94 & 0.92 & 0.03 \\
\hline Lactose & 1.32 & 1.22 & 1.27 & 1.30 & 0.06 \\
\hline Casein & 0.68 & 0.65 & 0.69 & 0.69 & 0.02 \\
\hline Feed efficiency $^{3}$ & $1.21^{\mathrm{y}}$ & $1.21^{\mathrm{y}}$ & $1.38^{\mathrm{x}}$ & $1.31^{\mathrm{xy}}$ & 0.07 \\
\hline \multicolumn{6}{|c|}{ Milk composition (\%) } \\
\hline Fat & 3.46 & 3.62 & 3.61 & 3.46 & 0.18 \\
\hline Protein & 3.31 & 3.44 & 3.36 & 3.31 & 0.06 \\
\hline Lactose & 4.73 & 4.75 & 4.70 & 4.72 & 0.04 \\
\hline Casein & 2.42 & 2.48 & 2.50 & 2.46 & 0.39 \\
\hline \multicolumn{6}{|c|}{$\overline{\mathrm{a}, \mathrm{b}}$ Means within a row with different superscripts differ $(P<0.05)$. } \\
\hline \multicolumn{6}{|c|}{${ }^{\mathrm{x}, \mathrm{y}}$ Means within a row with different superscripts differ $(P>0.05$ but $<0.1)$} \\
\hline \multicolumn{6}{|c|}{$\begin{array}{l}{ }^{1} \mathrm{HP}=\text { diet based on grazed pasture plus } 6 \mathrm{~kg} / \mathrm{d} \text { of a high } \mathrm{CP} \text { concentrate; } \mathrm{LP}=\text { diet based on grazed pasture } \\
\text { plus } 6 \mathrm{~kg} / \mathrm{d} \text { of a low } \mathrm{CP} \text { concentrate; } \mathrm{LP}+\mathrm{HMBi}=\text { diet based on grazed pasture plus } 6 \mathrm{~kg} / \mathrm{d} \text { of a low } \mathrm{CP} \text { con- } \\
\text { centrate containing supplementary } 2 \text {-hydroxy-4-methlythio butanoic acid }(\mathrm{HMBi}) ; \mathrm{LP} \text { Corn }=\text { diet based on } \\
\text { grazed pasture plus } 6 \mathrm{~kg} / \mathrm{d} \text { of a low } \mathrm{CP} \text { concentrate where corn grain replaces barley grain as the starch source. }\end{array}$} \\
\hline
\end{tabular}

higher for animals offered HP compared with those offered LP $(P<0.01)$, LP + HMBi $(P=0.05)$, or LP Corn $(P<0.01)$; N intake did not differ among animals offered LP, LP + HMBi, and LP Corn. Supplementary concentrate type had no effect $(P=0.19)$ on excretion of $\mathrm{N}$ in the feces. However, $\mathrm{N}$ excretion in the urine was higher for animals offered HP compared with those offered LP $(P<0.01)$, LP + HMBi $(P<0.01)$, and LP Corn $(P<0.01)$. Excretion of urinary $\mathrm{N}$ was not different among animals offered low CP concentrates. Milk N output was higher from animals offered HP compared with those offered LP $(P=0.07)$. Milk N output from animals offered LP + HMBi and LP Corn were not different from those offered HP. However, animals offered LP Corn had a greater milk $\mathrm{N}$ output compared with those offered LP $(P=0.08)$. Balance of PDI (PDI intake - PDI required for maintenance and production) was greater for HP compared with $\mathrm{LP}+\mathrm{HMBi}(P<$ $0.01)$ and LP Corn $(P<0.01)$ but not different from LP $(P=0.13)$. Rumen-degradable protein balance was higher for animals offered HP compared with those offered LP $(P=0.04)$ and LP Corn $(P=0.04)$ but not LP + HMBi. Milk urea nitrogen was not affected $(P=$ 0.32 ) by concentrate treatment.

The portion of ingested $\mathrm{N}$ recovered in the feces (feces $\mathrm{N}$ out/feed $\mathrm{N}$ in) was lower for animals offered HP compared with those offered LP $(P=0.01)$, LP + HMBi $(P<0.01)$, and LP Corn $(P<0.01)$. Ingested
$\mathrm{N}$ recovered in the urine (urine $\mathrm{N}$ out/feed $\mathrm{N}$ in) was greater for animals offered HP compared with LP + HMBi $(P=0.01)$ and LP Corn $(P=0.01)$. Animals offered LP also had a greater portion of ingested $\mathrm{N}$ recovered in the urine compared with those offered LP $+\operatorname{HMBi}(P=0.06)$ and LP Corn $(P<0.01)$, but not HP $(P=0.19)$. The portion of ingested $\mathrm{N}$ recovered in the milk (milk $\mathrm{N}$ out/feed $\mathrm{N}$ in) was higher for animals offered LP Corn compared with those offered HP ( $P$ $=0.02)$ and $\operatorname{LP}(P=0.03)$. The portion of ingested $\mathrm{N}$ recovered in the milk was not different among animals offered HP, LP, or LP + HMBi.

We found positive linear relationships (Figure 1) between $\mathrm{N}$ intake and excretion of $\mathrm{N}$ in the urine (Eq. [1], $P<0.001, \mathrm{R}^{2}=0.77$ ), feces (Eq. [2], $P<0.001, \mathrm{R}^{2}$ $=0.12$ ), and milk (Eq. [3], $P<0.001, \mathrm{R}^{2}=0.31$ ). We also found a positive linear relationship between urine $\mathrm{N}$ excretion and $\mathrm{RDP}_{\text {bal }}$ (Eq. [4], $P<0.001, \mathrm{R}^{2}=0.26$ ) and urine $\mathrm{N}$ excretion and PDI balance (Eq. [5], $P<$ $\left.0.001, R^{2}=0.21\right)$.

$$
\begin{gathered}
\text { Urinary N excretion }(\mathrm{kg} / \mathrm{d})=0.734( \pm 0.031) \\
\times \mathrm{N} \text { intake }(\mathrm{kg} / \mathrm{d})-0.158( \pm 0.016)
\end{gathered}
$$

Feces $\mathrm{N}$ excretion $(\mathrm{kg} / \mathrm{d})=0.108( \pm 0.023)$

$$
\times \mathrm{N} \text { intake }(\mathrm{kg} / \mathrm{d})+0.100( \pm 0.011),
$$


WHELAN ET AL.

Table 4. Effect of supplementary concentrate type on N partitioning

\begin{tabular}{|c|c|c|c|c|c|}
\hline \multirow[b]{2}{*}{ Item } & \multicolumn{4}{|c|}{$\operatorname{Diet}^{1}$} & \multirow[b]{2}{*}{ SEM } \\
\hline & $\mathrm{HP}$ & LP & $\mathrm{LP}+\mathrm{HMBi}$ & LP Corn & \\
\hline \multicolumn{6}{|l|}{ Intake $(\mathrm{kg} / \mathrm{d})$} \\
\hline Feed N & $0.545^{\mathrm{a}}$ & $0.473^{\mathrm{b}}$ & $0.500^{\mathrm{b}}$ & $0.474^{\mathrm{b}}$ & 0.017 \\
\hline $\mathrm{PDI}^{2}$ & $2.156^{\mathrm{a}}$ & $1.857^{\mathrm{b}}$ & $1.939^{\mathrm{b}}$ & $1.909^{\mathrm{b}}$ & 0.058 \\
\hline \multicolumn{6}{|l|}{$\mathrm{N}$ output $(\mathrm{kg} / \mathrm{d})$} \\
\hline Feces & 0.148 & 0.156 & 0.156 & 0.158 & 0.006 \\
\hline Urine & $0.261^{\mathrm{a}}$ & $0.202^{\mathrm{b}}$ & $0.207^{\mathrm{b}}$ & $0.177^{\mathrm{b}}$ & 0.015 \\
\hline Milk & $0.139^{\mathrm{x}}$ & $0.126^{\mathrm{y}}$ & $0.137^{\mathrm{xy}}$ & $0.138^{\mathrm{x}}$ & 0.005 \\
\hline \multicolumn{6}{|l|}{$\mathrm{N}$ recovery ${ }^{3}$} \\
\hline Feces & $0.272^{\mathrm{b}}$ & $0.324^{\mathrm{a}}$ & $0.317^{\mathrm{a}}$ & $0.341^{\mathrm{a}}$ & 0.012 \\
\hline Urine & $0.466^{\mathrm{a}}$ & $0.428^{\mathrm{ab}}$ & $0.408^{\mathrm{bc}}$ & $0.366^{\mathrm{c}}$ & 0.018 \\
\hline Milk & $0.257^{\mathrm{b}}$ & $0.264^{\mathrm{ab}}$ & $0.274^{\mathrm{ab}}$ & $0.282^{\mathrm{a}}$ & 0.007 \\
\hline PDI balance ${ }^{4}$ & $0.420^{\mathrm{a}}$ & $0.270^{\mathrm{ab}}$ & $0.174^{\mathrm{b}}$ & $0.193^{\mathrm{b}}$ & 0.057 \\
\hline MUN $(\mathrm{mmol} / \mathrm{L})$ & 1.828 & 1.771 & 1.900 & 1.755 & 0.119 \\
\hline $\mathrm{RDP}_{\text {bal }} 5$ & $0.140^{\mathrm{a}}$ & $0.049^{\mathrm{b}}$ & $0.087^{\mathrm{ab}}$ & $0.047^{\mathrm{b}}$ & 0.048 \\
\hline
\end{tabular}

${ }^{a-c}$ Means within a row with different superscripts differ $(P<0.05)$.

${ }^{\mathrm{x}, \mathrm{y}}$ Means within a row with different superscripts differ $(P>0.05$ but $<0.1)$.

${ }^{1} \mathrm{HP}=$ diet based on grazed pasture plus $6 \mathrm{~kg} / \mathrm{d}$ of a high $\mathrm{CP}$ concentrate; $\mathrm{LP}=$ diet based on grazed pasture plus $6 \mathrm{~kg} / \mathrm{d}$ of a low $\mathrm{CP}$ concentrate; $\mathrm{LP}+\mathrm{HMBi}=$ diet based on grazed pasture plus $6 \mathrm{~kg} / \mathrm{d}$ of a low $\mathrm{CP}$ concentrate containing supplementary 2-hydroxy-4-methlythio butanoic acid (HMBi); LP Corn = diet based on grazed pasture plus $6 \mathrm{~kg} / \mathrm{d}$ of a low $\mathrm{CP}$ concentrate where corn grain replaces barley grain as the starch source.

${ }^{2} \mathrm{PDI}=$ protein truly digested in the small intestine.

${ }^{3} \mathrm{~N}$ recovery $=\mathrm{N}$ out $[$ feces, urine, milk $(\mathrm{kg} / \mathrm{d})] / \mathrm{N}$ intake $(\mathrm{kg} / \mathrm{d})$.

${ }^{4} \mathrm{PDI}$ balance $=$ PDI intake $-(\mathrm{PDI}$ maintenance + PDI milk $)$.

${ }^{5} \mathrm{RDP}_{\text {bal }}=$ rumen-degradable PDI balance.

Milk N excretion $(\mathrm{kg} / \mathrm{d})=0.162( \pm 0.019)$

$\times \mathrm{N}$ intake $(\mathrm{kg} / \mathrm{d})+0.054( \pm 0.009)$,

Urinary N excretion $(\mathrm{kg} / \mathrm{d})=0.201( \pm 0.027)$

$\times \mathrm{RDP}_{\text {bal }}(\mathrm{kg} / \mathrm{d})+0.192( \pm 0.006)$,

Urinary N excretion $(\mathrm{kg} / \mathrm{d})=0.103( \pm 0.017)$

$\times$ PDI balance $(\mathrm{kg} / \mathrm{d})+0.185( \pm 0.007)$.

\section{DISCUSSION}

\section{DMI, Digestibility, Milk Production, and Milk Composition}

Animals used in this experiment were grazed together and received the same level of supplementary concentrate. This should have reduced the potential of pasture chemical composition, pasture availability, and concentrate supplementation rate as sources of variation in PDMI and dietary DMD, as observed in Vazquez and Smith (2000), Bargo et al. (2002), and Mulligan et al. (2004). The supplementary concentrates used in this experiment differed in terms of CP concentration (19 vs. $15 \%$ of DM) and starch source (barley vs. corn), both of which are thought to affect PDMI and DMD (Bargo et al., 2003; Gehman et al., 2006).
However, concentrate supplementation rates were likely too low for CP or starch source to affect either PDMI or dietary DMD in this experiment, consistent with the observations of Delahoy et al. (2003) and Mulligan et al. (2004), where similar concentrate supplementation rates were offered.

Reducing concentrate CP (HP vs. LP) decreased MY and yields of fat, protein, and lactose, consistent with observations of Mulligan et al. (2004). This result may 5 ] be partly attributed to the numeric reduction in PDMI and therefore energy intake (14.22 vs. $12.79 \mathrm{~kg}$ of $\mathrm{DM} / \mathrm{d}$ for HP and LP respectively). However, the HP concentrate contained more PDIA and a better profile of lysine and methionine than the LP concentrate, the combination of which likely supported increased MY (Kalscheur et al., 1999; NRC, 2001). The addition of $\mathrm{HMBi}$ to the low $\mathrm{CP}$ concentrate improved milk production (LP + HMBi vs. LP) to levels comparable with those of the HP, suggesting that available methionine may have limited milk production when LP was offered in this experiment. Animals offered LP + HMBi had the highest yields of milk fat. This result highlights the importance of methionine in lipoprotein synthesis and transport of triglycerides from the liver to the mammary gland (Pullen et al., 1989; Varvikko et al., 1999).

Replacing rolled barley with ground corn (LP vs. LP Corn) also gave an improvement in yields of milk, protein, and casein. The increase in milk yield and milk 


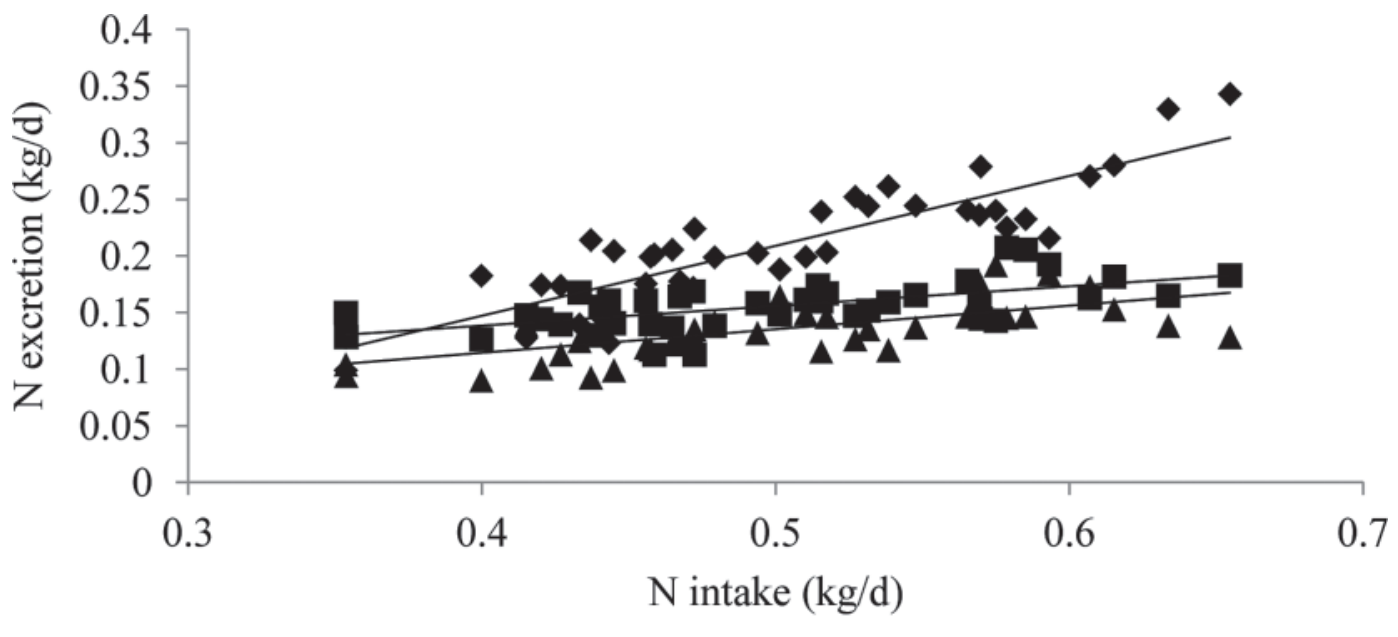

\section{$\bullet$ Urine $\mathrm{N}$-Feces N $\Delta$ Milk N}

Figure 1. Pattern of urine, feces, and milk $\mathrm{N}$ excretion plotted over the range of $\mathrm{N}$ intakes observed for cows.

constituent yield observed herein may be a result of increased dietary starch intake with LP Corn $(+207$ $\mathrm{g} / \mathrm{d}$ vs. other concentrates), the increased supply of PDIA, and better balance of lysine and methionine compared with LP concentrates. Corn starch is known to have a high degree of rumen resistance (HerreraSaldana et al., 1990) and is subsequently digested in the small intestine to yield glucose (Ørskov, 1986). In a companion study, Pierce et al. (2011) demonstrated that circulating glucose levels were increased when corn replaces barley. Increased circulating glucose and an improved supply of PDI may have improved nutrient availability to the mammary gland to support the extra milk production observed (Rius et al., 2010).

\section{Nitrogen Partitioning Study}

In calculating $\mathrm{N}$ partitioning in this experiment, it was assumed that negligible levels of $\mathrm{N}$ were retained in the animal. As BCS or BW did not change during the experiment, this is a valid assumption. Previously, Mulligan et al. (2004) and Steinshamn et al. (2006) published $\mathrm{N}$ partitioning data where $\mathrm{N}$ intake and fecal $\mathrm{N}$ were calculated using $n$-alkane markers while calculating urine $\mathrm{N}$ by difference, assuming negligible levels of $\mathrm{N}$ retention. More recently, Whelan et al. (2011) reported that $97 \%$ of ingested $\mathrm{N}$ was recovered in the feces, urine, and milk using total collections in metabolism stalls.

Nitrogen intake for the dairy cows in this study was within the range of that reported in Mulligan et al. (2004) and Burke et al. (2008). Nitrogen intake was higher for animals offered HP compared with other concentrate types, reflecting differences in $\mathrm{N}$ content of concentrates offered and the numerically higher pasture DMI observed. Similarly, the PDI supply was higher for animals offered HP compared with those offered low $\mathrm{CP}$ concentrate treatments. However, these differences were smaller as they include the potential for fermentable OM to contribute to microbial protein supply (Jarrige, 1989).

Although the lactating dairy cow utilizes ingested feed $\mathrm{N}$ with greater efficiency than other ruminants, a considerable portion (65 to $80 \%$ ) of feed $\mathrm{N}$ is still excreted in the feces and urine (Broderick, 2006). Fecal $\mathrm{N}$ excretion in this study was not affected by concentrate type and was poorly related to $\mathrm{N}$ intake (Eq. [2]), consistent with previous observations made for lactating dairy cows (Mulligan et al., 2004; Steinshamn et al., 2006). However, the portion of ingested feed N recovered in feces was much lower in animals offered HP compared with those offered other concentrate treatments. Fecal N, consisting largely of endogenous $\mathrm{N}$ and undigested feed $\mathrm{N}$, is less volatile than urea, the principal $\mathrm{N}$ component in urine. Therefore, increasing the portion of ingested $\mathrm{N}$ excreted in the feces at the expense of urinary $\mathrm{N}$ has environmental significance because of the reduced potential for $\mathrm{N}$ loss as $\mathrm{NH}_{3}$ (Bussink and Oenema, 1998), $\mathrm{N}_{2} \mathrm{O}$ (Tamminga, 1992), and $\mathrm{NO}_{3}{ }^{-}$leachate to water courses (Pakrou and Dillon, 1995).

Urinary $\mathrm{N}$ excretion in this experiment was strongly related to $\mathrm{N}$ intake (Eq. [1]), suggesting that as $\mathrm{N}$ intake increases, $\mathrm{N}$ recovery in the urine also increases. However, MUN was not affected by $\mathrm{N}$ intake. Milk urea $\mathrm{N}$ has been suggested to be an indicator for both $\mathrm{N}$ 
intake and urine $\mathrm{N}$ excretion (Kauffman and St-Pierre, 2001). However, when differences in $\mathrm{N}$ intake are smaller, MUN concentrations remain similar (OlmosColmenero and Broderick, 2006). For animals offered the HP concentrate treatment, the additional $\mathrm{N}$ intake associated with this feed was almost entirely recovered in the urine. In this experiment, reducing concentrate $\mathrm{CP}$ would have had the effect of increasing the ratio of FOM to $\mathrm{N}$ in the rumen, thus improving microbial $\mathrm{N}$ efficiency, and may have contributed to further reductions in urinary $\mathrm{N}$ excretion (van Vuuren et al., 1993). However, urinary $\mathrm{N}$ excretion was positively related to both $\mathrm{RDP}_{\text {bal }}$ (Eq. [4]) and PDI balance (Eq. [5]), suggesting that both rumen-derived $\mathrm{NH}_{3} \mathrm{~N}$ and $\mathrm{AA}$ not utilized for milk protein production contributed to urinary $\mathrm{N}$ excretion in this experiment. Supplementing low $\mathrm{CP}$ concentrate with HMBi (LP vs. LP + HMBi) did not infer a reduction in urinary $\mathrm{N}$ excretion. However, $\mathrm{N}$ intake was numerically greater with these diets and may have reduced the potential for HMBi to reduce urinary $\mathrm{N}$ excretion otherwise expected from the observed improvement in milk $\mathrm{N}$ efficiency. Replacing rolled barley with ground corn gave the lowest levels of urinary $\mathrm{N}$ excretion, partly reflecting the improvement in milk protein yield with these diets, but also reflecting the level of feed $\mathrm{N}$ intake observed for animals offered this concentrate type.

Interestingly, the portion of ingested $\mathrm{N}$ recovered in the urine was not reduced by reducing concentrate $\mathrm{CP}$ alone (HP vs. LP), reflecting the reduction in milk $\mathrm{N}$ output observed when LP replaced HP as the supplementary concentrate type. However, supplementing low $\mathrm{CP}$ concentrates with HMBi further reduced the portion of ingested feed $\mathrm{N}$ recovered in the urine. This result can be largely attributed to the improvement in milk $\mathrm{N}$ output (LP vs. LP + HMBi) to levels similar to those observed for animals offered HP despite differences in $\mathrm{N}$ intake between these 2 diets $(0.545$ vs. $0.500 \mathrm{~kg}$ of $\mathrm{N} / \mathrm{d}$ for HP and LP + HMBi, respectively). Similarly, Broderick et al. (2009) found that offering a source of rumen-protected methionine to low $\mathrm{CP}$ diets $(15.8 \%$ $\mathrm{CP})$ resulted in milk $\mathrm{N}$ output levels that approximated those of higher CP diets (17.1\% CP) and thus improved the efficiency of $\mathrm{N}$ use for milk while reducing the portion of ingested $\mathrm{N}$ recovered in the urine.

When LP Corn was offered, animals had the highest portion of ingested $\mathrm{N}$ recovered in the milk and concurrently the lowest portion of ingested $\mathrm{N}$ in the urine. This improvement in $\mathrm{N}$ efficiency can be attributed to the fact that LP Corn supplied more starch and PDI than animals offered LP, thus improving nutrient availability to the mammary gland for milk protein synthesis. Previously, Rius et al. (2010) demonstrated that improvements in the supply of AA and glucose to the mammary gland improve milk protein synthesis. Promoting improved mammary gland uptake of AA at a given supply of feed $\mathrm{N}$ will reduce liver degradation of AA to urea and urinary $\mathrm{N}$ excretion.

\section{CONCLUSIONS}

Manipulation of the supplementary concentrate offered to grazing dairy cows in early lactation is a viable strategy to alter $\mathrm{N}$ partitioning, thus potentially reducing the environmental burden of grass-based dairy production systems. However, maintaining milk production in this experiment required supplementary methionine or the substitution of rolled barley with ground corn in low CP concentrates.

\section{ACKNOWLEDGMENTS}

Funding for this research was provided under the National Development Plan, through the Research Stimulus Fund, administered by the Department of Agriculture, Fisheries and Food, Ireland (\#RSF 07536). Additionally, the authors acknowledge the contribution of the farm and laboratory staff at UCD Lyons Research Farm (Newcastle, Dublin, Ireland).

\section{REFERENCES}

Allison, R. D., and P. C. Garnsworthy. 2002. Increasing the digestible undegraded protein intake of lactating dairy cows by feeding fishmeal or a rumen protected vegetable protein blend. Anim. Feed Sci. Technol. 96:69-81.

Bargo, F., L. D. Muller, J. E. Delahoy, and T. W. Cassidy. 2002. Milk response to concentrate supplementation of high producing dairy cows grazing at two pasture allowances. J. Dairy Sci. 85:17771792 .

Bargo, F., L. D. Muller, E. S. Kolver, and J. E. Delahoy. 2003. Invited review: Production and digestion of supplemented dairy cows on pasture. J. Dairy Sci. 86:1-42.

Broderick, G. A. 2003. Effects of varying dietary protein and energy levels on the production of lactating dairy cows. J. Dairy Sci. 86:1370-1381.

Broderick, G. A. 2006. Nutritional strategies to reduce crude protein in dairy diets. Page 1 in Proc. 21st Southwest Nutrition and Management Conference, Tempe, AZ. University of Arizona, Tucson, AZ.

Broderick, G. A., M. J. Stevenson, and R. A. Patton. 2009. Effect of dietary protein concentration and degradability on response to rumen-protected methionine in lactating dairy cows. J. Dairy Sci. 92:2719-2728.

Broderick, G. A., M. J. Stevenson, R. A. Patton, N. E. Lobos, and J. J. Olmos Colmenero. 2008. Effect of supplementing rumen-protected methionine on production and nitrogen excretion in lactating dairy cows. J. Dairy Sci. 91:1092-1102.

Burke, F., M. A. O'Donovan, J. J. Murphy, F. P. O'Mara, and F. J. Mulligan. 2008. Effect of pasture allowance and supplementation with maize silage and concentrates differing in crude protein concentration on milk production and nitrogen excretion by dairy cows. Livest. Sci. 114:325-335.

Bussink, D. W., and O. Oenema. 1998. Ammonia volatilization from dairy farming systems in temperate areas: A review. Nutr. Cycl. Agroecosyst. 51:19-33. 
Casey, J. W., and N. M. Holden. 2005. Analysis of greenhouse gas emissions from the average Irish milk production system. Agric. Syst. 86:97-114.

Castillo, A. R., E. Kebreab, D. E. Beever, J. H. Barbi, J. D. Sutton, H. C. Kirby, and J. France. 2001. The effect of energy supplementation on nitrogen utilization in lactating dairy cows fed grass silage diets. J. Anim. Sci. 79:240-246.

Delahoy, J. E., L. D. Muller, F. Bargo, T. W. Cassidy, and L. A. Holden. 2003. Supplemental carbohydrate sources for lactating dairy cows on pasture. J. Dairy Sci. 86:906-915.

Dove, H., and R. W. Mayes. 2006. Protocol for the analysis of n-alkanes and other plant-wax compounds and for their use as markers for quantifying the nutrient supply of large mammalian herbivores. Nat. Protoc. 1:1680-1697.

European Communities. 2009. Good Agricultural Practice for Protection of Waters Regulations. Statutory Instrument no. 101. European Union, Brussels, Belgium.

Gehman, A. M., J. A. Bertrand, T. C. Jenkins, and B. W. Pinkerton. 2006. The effect of carbohydrate source on nitrogen capture in dairy cows on pasture. J. Dairy Sci. 89:2659-2667.

Herrera-Saldana, R. E., J. T. Huber, and M. H. Poore. 1990. Dry matter, crude protein, and starch degradability of five cereal grains. J. Dairy Sci. 73:2386-2393.

Hyde, B. P., O. T. Carton, P. O'Toole, and T. H. Misselbrook. 2003. A new inventory of ammonia emissions from Irish agriculture. Atmos. Environ. 37:55-62.

IDF. 2004. Milk-Determination of Casein Nitrogen Content. Part 2: Direct Method. IDF 29-2:2004(E). International Dairy Federation, Brussels, Belgium.

Jarrige, R. 1989. Ruminant Nutrition: Recommended Allowances and Feed Tables. John Libbey, Paris, France.

Kalscheur, K. F., J. H. Vandersall, R. A. Erdman, R. A. Kohn, and E. Russek-Cohen. 1999. Effects of dietary crude protein concentration and degradability on milk production responses of early, mid, and late lactation dairy cows. J. Dairy Sci. 82:545-554.

Kauffman, A. J., and N. R. St-Pierre. 2001. The relationship of milk urea nitrogen to urine nitrogen excretion in Holstein and Jersey cows. J. Dairy Sci. 84:2284-2294.

Kebreab, E., A. R. Castillo, D. E. Beever, D. J. Humphries, and J. France. 2000. Effects of management practices prior to and during ensiling and concentrate type on nitrogen utilization in dairy cows. J. Dairy Sci. 83:1274-1285.

Mayes, R. W., C. S. Lamb, and P. M. Colgrove. 1986. The use of dosed and herbage n-alkanes as markers for the determination of herbage intake. J. Agric. Sci. 107:161-170.

McDonald, P., R. Edwards, J. Greenhalgh, and C. Morgan. 2002. Animal Nutrition. 6th ed. Pearson Education Ltd., Essex, UK.

Mulligan, F. J., P. Dillon, J. J. Callan, M. Rath, and F. P. O'Mara 2004. Supplementary concentrate type affects nitrogen excretion of grazing dairy cows. J. Dairy Sci. 87:3451-3460.

Noftsger, S., and N. R. St-Pierre. 2003. Supplementation of methionine and selection of highly digestible rumen undegradable protein to improve nitrogen efficiency for milk production. J. Dairy Sci. 86:958-969.

NRC. 2001. Nutrient Requirements of Dairy Cattle. 7th rev. ed. Natl. Acad. Sci., Washington D.C

Olmos-Colmenero, J. J., and G. A. Broderick. 2006. Effect of dietary crude protein concentration on milk production and nitrogen utilization in lactating dairy cows. J. Dairy Sci. 89:1704-1712.

Ørskov, E. R. 1986. Starch digestion and utilization in ruminants. J. Anim. Sci. 63:1624-1633.

Pakrou, N., and P. Dillon. 1995. Preferential flow, nitrogen transformations and $15 \mathrm{~N}$ balance under urine-affected areas of irrigated and non-irrigated clover-based pastures. J. Contam. Hydrol. 20:329 347.

Peyraud, J. L., L. Astigarraga, and P. Faverdin. 1997. Digestion of fresh perennial ryegrass fertilized at two levels of nitrogen by lactating dairy cows. Anim. Feed Sci. Technol. 64:155-171.

Phipps, R. H., C. K. Reynolds, D. I. Givens, A. K. Jones, P. A. Geraert, E. Devillard, and R. Bennett. 2008. Short communication: Effects of 2-hydroxy-4-(methylthio) butanoic acid isopropyl ester on milk production and composition of lactating Holstein dairy cows. J. Dairy Sci. 91:4002-4005.

Pierce, K. M., S. J. Whelan, J. J. Callan, and F. J. Mulligan. 2011. Effect of supplementary concentrate type on energy balance and blood metabolites in early lactation dairy cows offered grazed pasture. J. Dairy Sci. 94(E-Suppl. 1):769. (Abstr.)

Pullen, D. L., D. L. Palmquist, and R. S. Emery. 1989. Effect on days of lactation and methionine hydroxy analogue on incorporation of plasma fatty acids into plasma triglycerides. J. Dairy Sci. 72:49-58.

Rius, A. G., J. A. D. R. N. Appuhamy, J. Cyriac, D. Kirovski, O. Becvar, J. Escobar, M. L. McGilliard, B. J. Bequette, R. M. Akers, and M. D. Hanigan. 2010. Regulation of protein synthesis in mammary glands of lactating dairy cows by starch and amino acids. J. Dairy Sci. 93:3114-3127.

Rulquin, H., R. Verite, and J. Guinard-Flament. 2001. Acides aminés digestibles dans l'intestin. Le système AADI et les recommandations d'apport pour la vache laitière INRA. Prod. Anim. 14:265274.

SAS Institute. 2004. SAS User's Guide. 9.1.2 ed. SAS Institute Inc., Cary, NC

Schor, A., and G. A. Gagliostro. 2001. Undegradable protein supplementation to early-lactation dairy cows in grazing conditions. J. Dairy Sci. 84:1597-1606.

Steinshamn, H., M. Höglind, T. H. Garmo, E. Thuen, and U. T. Brenøe. 2006. Feed nitrogen conversion in lactating dairy cows on pasture as affected by concentrate supplementation. Anim. Feed Sci. Technol. 131:25-41.

Tamminga, S. 1992. Nutrition management of dairy cows as a contribution to pollution control. J. Dairy Sci. 75:345-357.

Van Soest, P. J., J. B. Robertson, and B. A. Lewis. 1991. Methods for dietary fiber, neutral detergent fiber, and nonstarch polysaccharides in relation to animal nutrition. J. Dairy Sci. 74:3583-3597.

van Vuuren, A. M., F. Krol-Kramer, R. A. Van der Lee, and H. Corbijn. 1992. Protein digestion and intestinal amino acids in dairy cows fed fresh Lolium perenne with different nitrogen contents. J. Dairy Sci. 75:2215-2225.

van Vuuren, A. M., C. J. Van Der Koelen, H. Valk, and H. De Visser. 1993. Effects of partial replacement of ryegrass by low protein feeds on rumen fermentation and nitrogen loss by dairy cows. J. Dairy Sci. 76:2982-2993.

Varvikko, T., A. Vanhatalo, T. Jalava, and P. Huhtanen. 1999. Lactation and metabolic responses to graded abomasal doses of methionine and lysine in cows fed grass silage diets. J. Dairy Sci. 82:2659-2673.

Vazquez, O. P., and T. R. Smith. 2000. Factors affecting pasture intake and total dry matter intake in grazing dairy cows. J. Dairy Sci. $83: 2301-2309$.

Whelan, S. J., F. J. Mulligan, B. Flynn, C. McCarney, and K. M. Pierce. 2011. Effect of forage source and a supplementary methionine hydroxy analogue on nitrogen balance in lactating dairy cows offered a low-crude protein diet. J. Dairy Sci. 94:5080-5089. 